\title{
TINGKAT PARTISIPASI ANGGOTA KELOMPOK TANI DALAM KEGIATAN PENANGKARAN BENIH KEDELAI (Glycine max L) DI KECAMATAN RAMAN UTARA KABUPATEN LAMPUNG TIMUR
}

\author{
(The Participation Level of Farmer Group Members on Soybean Seed (Glycine max L) Production \\ in Raman Utara District of Lampung Timur) \\ Dhevi Maryanti, Sumaryo Gs, Suarno Sadar
}

Jurusan Agribisnis, Fakultas Pertanian, Universitas Lampung, Jl.Prof. Dr. Soemantri Brojonegoro No.1 Bandar Lampung 35145, Telp. 085764344133, e-mail: Dhevimaryanti90@ gmail.com

\begin{abstract}
This research aims to analyze the participation level of farmer group members on soybean seed production, and factors related to the participation level. This research was conducted in Rejo Binangun village, North Raman Sub-district. The respondents of this study were 36 soybean farmers selected by using stratified random sampling. The participation level of farmer group members on soybean seed production in this research is analyzed descriptively. The hypothesis was analyzed by using Rank Spearman correlation. The results showed that the participation rate of farmer group members in soybean seed production activities in North Raman sub-district of East Lampung Regency is classified as moderate. Factors significantly related to the participation rate of members of farmer groups are the type of non-formal education, level of cosmopolitan character, and level of knowledge.
\end{abstract}

Key words: factors related to participation, participation, soybean seed production

\section{PENDAHULUAN}

Provinsi Lampung adalah salah satu provinsi di Indonesia yang sebagian besar masyarakatnya bermatapencaharian di sektor pertanian dalam arti sempit di sektor pertanian tanaman pangan yaitu petani penghasil kedelai. Salah satu kabupaten di Provinsi Lampung yang memiliki potensi di bidang tanaman pangan dengan komoditas tanaman kedelai adalah Kabupaten Lampung Timur. Kabupaten Lampung Timur memiliki luas panen sebesar $1.285,00$ ha yang menempati posisi pertama dari 15 kabupaten/kota dalam urutan luas panen di Provinsi Lampung.

Selain itu, Kabupaten Lampung Timur memiliki tingkat produktivitas untuk tanaman kedelai yang cukup tinggi yaitu sebesar 12,33 ton/ha dan menempati posisi ke-5 dari 15 kabupaten/kota. Salah satu Kecamatan di Kabupaten Lampung Timur yang memiliki tingkat produksi kedelai tertinggi yaitu Kecamatan Raman Utara, dengan produksi kedelai sebesar 353,00 ton pada tahun 2015 (BPS 2015). Desa Rejo Binangun yaitu merupkan desa penghasil kedelai yang cukup tinggi yaitu sebesar 94,10 ton pada tahun 2015 dibanding dengan desa lainnya. Hal ini menunjukkan bahwa dari sembilan desa yang ada di Kecamatan Raman Utara, Desa Rejo Binangun memiliki luas lahan, produksi, dan produktivitas yang cukup tinggi dari tahun 2013-2015 karena kelompok tani mengikuti kegiatan penangkaran benih kedelai secara berkelanjutan. Menurut (BKSDA 2014) penangkaran benih adalah upaya perbanyakan melalaui pengembangbiakan dan pembesaran tumbuhan dengan mempertahankan kemurnian jenisnya. Tujuan dari kegiatan penangkaran benih kedelai adalah untuk mendapatkan spesimen tumbuhan dalam jumlah, mutu, kemurnian jenis dan keanekaragaman genetik yang terjamin.

Namun kegiatan penangkaran benih kedelai tidak secara keseluruhan diikuti oleh kelompok tani yang ada di Kecamatan Raman Utara, melainkan hanya di Desa Rejo Binangun. Oleh karena itu kegiatan penangkaran benih kedelai di Desa Rejo Binangun memang sangat penting untuk dilakukan, hal ini dikarenakan untuk menunjang ketersediaan bahan baku kedelai yang berkualitas di Lampung, khususnya di Kabupaten Lampung Timur.

Keberhasilan pembangunan pertanian tidak terlepas dari adanya partisipasi masyarakat, maka dari itu keberhasilan kegiatan penangkaran benih kedelai juga tidak terlepas dari adanya partisipasi anggota kelompok tani dalam mencapai tujuan kegiatan penangkaran. Keikutsertaaan kelompok tani lebih ditekankan agar petani merasa memiliki 
tahap perencanaan, pelaksanaan, pemantauan dan evaluasi serta pemanfaatan hasil kegiatan. Namun ditingkat partisipasi kelompok tani berhubungan dengan beberapa faktor seperti, jenis pendidikan nonformal, tingkat motivasi petani, tingkat kekosmopolitan petani dan tingkat pengetahuan petani tentang program. Tujuan penelitian ini adalah mengetahui tingkat partisipasi anggota kelompok tani dalam kegiatan penangkaran benih kedelai dan faktor-faktor yang berhubungan dengan partisipasi anggota kelompok tani dalam kegiatan penangkaran benih kedelai di wilayah kerja BP3K Raman Utara Kabupaten Lampung Timur.

\section{METODE PENELITIAN}

Penelitian ini dilakukan di Desa Rejo Binangun Kecamatan Raman Utara Kabupaten Lampung Timur pada bulan Agustus sampai september 2017. Pemilihan lokasi ditentukan secara sengaja (purposive), dengan pertimbangan bahwa Desa Rejo Binangun memiliki tingkat produksi kedelai paling tinggi dan mengikuti kegiatan penangkaran benih kedelai. Penentuan jumlah sampel petani menggunakan rumus Yamane (1967) dalam Rakhmat (2002), yaitu:

$\mathrm{n}=\frac{\mathrm{N}}{\mathrm{N}(\mathrm{d})^{2}+1}$

$\mathrm{n}=\frac{58}{58(0,1)^{2}+1}=36$

Keterangan:

$\mathrm{n}=$ Jumlah sampel

$\mathrm{N}=$ Jumlah populasi petanibinaan (58 orang)

$\mathrm{D}=$ Tingkat presisi (ditetapkan $10 \%$ dengan tingkat kepercayaan 95\%)

Berdasarkan rumus tersebut, diperoleh jumlah responden petani sebaak 36 orang, kemudian jumlah sampel petani dari setiap wilayah kerja penyuluh pertanian ditentukan menggunakan metode alokasi proporsional dengan rumus Nasir (1998), yaitu

$\mathrm{na}=\frac{\mathrm{Na}}{\mathrm{N}} \mathrm{x} \mathrm{n}$

Keterangan:

$\mathrm{Na}=$ Jumlah sampel petani di wilayah binaan penyuluh pertanian

$\mathrm{n} \quad=$ Jumlah sampel petani keseluruhan

$\mathrm{N}=$ Jumlah populasi petani keseluruhan

$\mathrm{Na}=$ Jumlah populasi petani di wilayah binaan penyuluh pertanian
Responden pada penelitian ini adalah anggota kelompok tani di Desa Rejo Binangun sebanyak 36 orang. Metode pangambilan petani sampel dilakukan dengan menggunakan metode acak sederhana (Simple Random Sampling) yaitu metode yang digunakan untuk memilih sampel dari populasi dengan cara sedemikian rupa sehingga setiap anggota populasi mempunyai peluang yang sama besar untuk diambil sebagai sampel.

Metode penelitian ini adalah metode survei dan metode dalam penelitian ini merujuk pada Singarimbun dan Effendi (1989), yaitu metode penelitian yang mengambil sampel dari satu populasi dan menggunakan kuesioner sebagai alat pengumpul data yang pokok. Jenis data pada penelitian adalah data primer dan data sekunder. Data primer diperoleh langsung dari responden, sedangkan data sekunder diperoleh melalui catatan atau laporan yang ada di BP3K Kecamatan Raman Utara, BP4K dan BPS Kabupaten Lampung Timur serta BPS Provinsi Lampung. Pengumpulan data dilakukan dengan wawancara terstruktur dan dokumentasi.

Pengukuran tingkat partisipasi anggota kelompok tani (Y) merujuk pada Soetomo (2008) dalam Andreeyan (2014) mengemukakan tentang empat macam kegiatan yang menunjukkan partisipasi masyarakat didalam kegiatan pembangunan, yang di ukur berdasarkan empat jenis indikator yaitu perencanaan, pelaksanaan, monitoring, evaluasi, dan pemanfaatan hasil.

Variabel bebas $(\mathrm{X})$ pada penelitian ini terdiri dari faktor-faktor yang diduga berhubungan dengan tingkat partisipasi anggota kelompok tani, yaitu jenis pendidikan nonformal, tingkat motivasi petani, tingkat kekosmopolitan petani dan tingkat pengetahuan petani tentang program. Tingkat partisipasi anggota kelompok tani diukur dengan skor tiga, dua dan satu, selanjutnya skor-skor tersebut diklasifikasikan menjadi tinggi, sedang dan rendah. Pengolahan data pada penelitian ini dilakukan menggunakan metode tabulasi, namun untuk analisis data yaitu menggunakan analisis deskriptif dan statistik.

Tingkat partisipasi anggota kelompok tani dalam kegiatan penangkaran benih kedelai dianalisis secara deskriptif dan hipotesis hubungan antara variabel $\mathrm{X}$ dan $\mathrm{Y}$ dianalisis menggunakan uji korelasi Rank Spearman menurut Siegel (1986), dengan pertimbangan bahwa menurut Hadi, Effendi, Hasanuddin (2013), yaitu menggunakan 
analisis tersebut karena dalam penelitian ini akan melihat hubungan antara kedua variabel yang diuji.

Kriteria pengambilan keputusan:

1. Jika signifikansi $\leq \alpha$, maka hipotesis diterima, pada $(\alpha)=0,05$ berarti terdapat hubungan nyata antara kedua variabel yang diuji.

2. Jika signifikansi $>\alpha$, maka hipotesis ditolak, pada $(\alpha)=0,05$ berarti tidak terdapat hubungan nyata antara kedua variabel yang diuji.

\section{HASIL DAN PEMBAHASAN}

\section{A. Deskripsi Faktor yang Diduga Berhubungan Dengan Tingkat Partisipasi Anggota Kelompok Tani Dalam Kegiatan Penangkaran Benih Kedelai}

Faktor yang diduga berhubungan dengan tingkat partisipasi anggota kelompok tani dalam kegiatan penangkaran benih kedelai yaitu jenis pendidikan nonformal $\left(X_{1}\right)$, tingkat motivasi $\left(X_{2}\right)$, tingkat kekosmopolitan $\left(\mathrm{X}_{3}\right)$ dan tingkat pengetahuan petani tentang program $\left(\mathrm{X}_{4}\right)$.

Jenis pendidikan nonformal petani $\left(\mathrm{X}_{1}\right)$ adalah jalur pendidikan di luar pendidikan formal yang dapat dilaksanakan secara terstruktur dan berjenjang. Jenis pendidikan nonformal dalam penelitian ini yaitu berupa kegiatan pelatihan, kegiatan magang dan kegiatan kursus tani.

Materi kegiatan pelatihan dalam penangkaran benih kedelai, meliputi penyusunan RDK/RDKK, kemampuan memupuk modal dan pemanfaatan pendapatan rasional yang diadakan oleh dinas pertanian, dan peningkatan hubungan lembaga dengan berbagai jenis koperasi. Data tersebut dapat dilihat pada Tabel 1.

Tingkat motivasi petani adalah dorongan yang ada pada diri petani yang dapat menggerakkan atau membangkitkan petani agar mau mengikuti suatu kegiatan yang dilihat berdasarkan apa yang memotiviasi dan siapa yang memotivasi petani dalam mengikuti kegiatan. Tingkat motivasi petani $\left(\mathrm{X}_{2}\right)$ dalam kegiatan penangkaran benih kedelai menunjukkan hasil bahwa tingkat motivasi petani berada dalam klasifikasi tinggi, hal ini telihat dari hasil persentase yang didapat 80,55 persen. Berdasarkan hasil data yang sudah dikumpulkan, bahwa terdiri dari 29 orang $(80,55 \%)$ memiliki motivasi yang tinggi dalam mengikuti kegiatan penangkaran benih kedelai, sedangkan enam orang (16,67 \%) memiliki motivasi yang sedang dalam mengikuti kegiatan penangkaran benih kedelai dan satu orang $(2,77 \%)$ memiliki motivasi yang rendah dalam mengikuti kegiatan penangkaran benih kedelai. Berdasarkan hasil penelitian di lapangan, motivasi petani berasal dari dalam diri mereka sendiri.

Anggota kelompok tani di Desa Rejo Binangun yang memiliki tingkat motivasi tinggi dalam mengikuti kegiatan penangkaran benih kedelai menyatakan dengan adanya kegiatan tersebut mereka bisa mengetahui dan memahami cara budidaya kedelai yang baik, metode penangkaran untuk benih kedelai, penggunaan pupuk dan mengatasi hama penyakit pada tanaman kedelai.

Beberapa responden penelitian yang termotivasi oleh penyuluh lapang dan sosialisasi dari Dinas Pertanian terkait dengan kegiatan penangkaran benih kedelai, dikarenakan petani mulai memiliki kemauan dan tertarik dengan mengikuti kegiatan penangkaran benih kedelai dengan begitu petani dapat mensejahterakan diri mereka dan keluarga serta petani beranggapan dengan mengikuti kegiatan tersebut, pendapatan dan produktivitas usahatani kedelai mereka dapat meningkat. motivasi petani dapat dilihat pada Tabel 2 .

Tingkat kekosmopolitan adalah salah satu sifat yang menggambarkan keterbukaan seorang terhadap lingkungan yang berada di luar sistem sosialnya hal ini dilakukan untuk mengetahui frekuensi petani dalam mengadakan kontak media informasi (koran, majalah, radio, dan televisi).

Tabel 1. Sebaran responden berdasarkan jenis pendidikan noformal petani

\begin{tabular}{ccc}
\hline $\begin{array}{c}\text { Jenis pendidikan } \\
\text { nonformal }\end{array}$ & $\begin{array}{c}\text { Jumlah Responden } \\
\text { (orang) }\end{array}$ & $\begin{array}{c}\text { Persentase } \\
(\%)\end{array}$ \\
\hline Pelatihan & 36 & 100 \\
Magang & - & - \\
Kursus & - & - \\
\hline Jumlah & 36 & 100,00 \\
\hline Sumber : Data Primer, 2017 & &
\end{tabular}

Tabel 2. Sebaran responden berdasarkan tingkat motivasi petani

\begin{tabular}{cccc}
\hline $\begin{array}{c}\text { Interval Motivasi } \\
\text { Petani } \\
\text { (skor) }\end{array}$ & $\begin{array}{c}\text { Klasifi- } \\
\text { kasi }\end{array}$ & $\begin{array}{c}\text { Jumlah } \\
\text { Responden } \\
\text { (orang) }\end{array}$ & $\begin{array}{c}\text { Persentase } \\
(\%)\end{array}$ \\
\hline $2,000-3,438$ & Rendah & 1 & 2,778 \\
$3,439-4,877$ & Sedang & 6 & 16,67 \\
$4,878-6,316$ & Tinggi & 29 & 80,55 \\
\hline Jumlah & & 36 & 100,00 \\
\hline Rata-rata & 5,89 (tinggi) & &
\end{tabular}

Sumber : Data Primer, 2017 
Tingkat kosmopolit petani dalam penelitian ini yaitu menggambarkan hubungan petani penangkar benih kedelai dengan sistem lain di luar sistem sosialnya. Tingkat kekosmopolitan petani penangkar benih kedelai dilihat berdasarkan frekuensi kontak dengan anggota kelompok lain.

Tingkat kekosmopolitan $\left(\mathrm{X}_{3}\right)$ diklasifikasikan menjadi tiga kelas yaitu kurang kosmopolit, cukup kosmopolit dan kosmopolit. Hasil penelitian tingkat kekosmopolitan petani berada pada klasifikasi cukup kosmopolit yaitu yaitu 47,22 persen. Berdasarkan hasil data penelitian tingkat kekosmopolitan petani yaitu 16 orang $(44,44 \%)$ berada dalam posisi yaitu kurang kosmopolit. Hal ini dikarenakan sebagian responden tidak memanfaatkan media massa seperti televisi dan surat kabar untuk memperoleh informasi tentang pertanian dan kegiatan usahatani, 17 orang $(47,22 \%)$ cukup kosmopolit, dan 16 orang $(8,33 \%)$ kosmopolit.

Berdasarkan hasil data penelitian di lapangan, responden petani yang memiliki tingkat kekosmopolitan tinggi menyatakan bahwa mereka sering mengadakan pertemuan atau anjangsana dengan tokoh masyarakat dari desa lain, dan sebagian besar responden menjawab bahwa responden menggunakan media elektronik untuk dimanfaatkan selain sebagai sarana hiburan seperti menonton berita, mendengarkan musik, atau membaca berita di surat kabar juga sebagai sarana untuk menambah wawasan tentang isu-isu yang berkaitan dengan pertanian masa kini. Hal ini dapat dilihat pada Tabel 3.

Tingkat pengetahuan petani $\left(\mathrm{X}_{4}\right)$ yang dimaksud dalam penelitian ini adalah Tingkat pengetahuan dalam kegiatan penangkaran benih kedelai. Hal ini dapat dilihat dari seberapa banyak penguasaan materi serta ilmu yang telah diterapkan nantinya tentang kegiatan penangkaran benih kedelai.

Tabel 3. Sebaran responden berdasarkan tingkat kekosmopolitan petani

\begin{tabular}{llcr}
\hline $\begin{array}{c}\text { Interval } \\
\text { kekosmpolitan } \\
\text { (skor) }\end{array}$ & Klasifikasi & $\begin{array}{c}\text { Jumlah } \\
\text { Responden } \\
\text { (orang) }\end{array}$ & $\begin{array}{c}\text { Persentase } \\
(\%)\end{array}$ \\
\hline $13,572-17,441$ & $\begin{array}{l}\text { Kurang } \\
\text { Kosmopolit }\end{array}$ & 16 & 44,44 \\
$17,442-21,311$ & $\begin{array}{l}\text { Cukup } \\
\text { Kosmopolit }\end{array}$ & 17 & 47,22 \\
$21,312-25,178$ & Kosmopolit & 3 & 8,33 \\
\hline Jumlah & \multicolumn{3}{c}{36} \\
\hline Rata-rata & 18,06 Cukup Kosmopolit \\
\hline Sumber : Data Primer, 2017
\end{tabular}

Berdasarkan hasil data penelitian, mengindikasikan bahwa responden yang memiliki tingkat pengetahuan yang masuk ke dalam klasifikasi rendah sebanyak 27 orang (75\%), sedangkan responden yang memiliki tingkat pengetahuan yang termasuk klasifikasi sedang sebanyak tujuh orang $(19,44 \%)$, dan tingkat pengetahuan yang masuk kedalam klasifikasi tinggi hanya dua orang $(5,56 \%)$.

Tingkat pengetahuan petani tentang program yaitu berada pada klasifikasi rendah dengan hasil pesentase 75 persen. Rata-rata nilai hasil data penelitian tingkat pengetahuan tentang kegiatan penangkaran benih kedelai termasuk dalam klasifikasi rendah yaitu 3,94 artinya petani yang ikut dalam kegiatan penangkaran benih kedelai mempunyai pengetahuan yang rendah tentang kegiatan penangkaran benih kedelai. Kegiatan tersebut berupa kegiatan penyeleksian benih kedelai berkualitas, proses budidaya sampai perawatan tanam benih, uji lapangan untuk proses tanam benih kedelai, kemampuan memupuk modal dan memanfaatkan pendapatan.

Pengetahuan responden tentang kegiatan penangkaran benih kedelai ini termasuk dalam kriteria kurang, baik dalam inti dari kegiatan program, tujuan, serta manfaat dari kegiatan penangkaran benih kedelai. Hasil penelitian ini sejalan dengan penelitian yang dilakukan Wijaya (2010) yang menyatakan bahwa tingkat pengetahuan tentang program berhubungan nyata dengan tingkat partisipasi petani. Hasil data sebaran responden dapat dilihat dari hasil persentase pada Tabel 4 .

Tabel 4. Sebaran responden berdasarkan tingkat pengetahuan petani tentang program

\begin{tabular}{cccr}
\hline $\begin{array}{c}\text { Interval } \\
\text { Tingkat } \\
\text { pengetahuan } \\
\text { petani } \\
\text { (skor) }\end{array}$ & Klasifikasi & $\begin{array}{c}\text { Jumlah } \\
\text { Responden } \\
\text { (orang) }\end{array}$ & $\begin{array}{c}\text { Persentase } \\
(\%)\end{array}$ \\
\hline $3,000-4,791$ & Rendah & 27 & 75 \\
$4,792-6,583$ & Sedang & 7 & 19,44 \\
$6,584-8,373$ & Tinggi & 2 & 5,56 \\
\hline Jumlah & & 36 & 100,00 \\
\hline Rata-rata & 3,94 (Rendah) & & \\
\hline Sumber : Data Primer, 2017 & & \\
& & & \\
& & & \\
& &
\end{tabular}




\section{B. Deskripsi Variabel Y (Tingkat Partisipasi Anggota Kelompok Tani yang Diukur Berdasarkan Variabel)}

Menurut Davis (2000) partisipasi adalah suatu keterlibatan mental dan emosi seseorang untuk pencapaian tujuan dan ikut bertanggung jawab di dalamnya. Partisipasi adalah suatu gejala demokrasi dan keterlibatan seorang dalam suatu perencanaan serta dalam pelaksanaan dan juga ikut memikul tanggung jawab.

\section{Partisipasi petani dalam perencanaan}

Partisipasi dalam tahap perencanaan kegiatan penangkaran benih kedelai, yaitu keterlibatan petani dalam perencanaan kegiatan penangkaran benih kedelai. Partisipasi dalam perencanaan kegiatan yaitu berupa penyiapan lahan atau lokasi yang tepat serta penyiapan sarana produksi, penentuan musim tanam, penentuan waktu tanam.

Indikator yang dipakai dalam tingkat partisipasi anggota kelompok tani dalam kegiatan penangkaran benih kedelai meliputi partisipasi dalam tahap perencanaan, tahap pelaksanaan, tahap penilaian dan tahap manfaat program. Berdasarkan hasil penelitian diketahui bahwa sebagian besar responden yaitu dengan 15 orang $(41,67 \%)$ menyatakan tingkat partisipasi petani dalam perencanaan kegiatan penangkaran benih kedelai di Kecamatan Raman Utara masuk dalam klasifikasi tinggi, 12 orang $(33,33 \%)$ masuk klasifikasi sedang, dan sembilan orang (25\%) masuk dalam klasifikasi rendah.

Rata-rata tingkat partisipasi petani dalam perencanaan kegiatan penangkaran benih kedelai diklasifikasikan sedang yaitu sebesar 9,810, artinya tingkat partisipasi petani di Kecamatan Raman Utara sudah cukup memiliki kemauan untuk berpartisipasi dalam kegiatan penangkaran benih kedelai. Hal ini dapat dilihat pada Tabel 5.

Tabel 5. Sebaran responden berdasarkan tingkat partisipasi petani dalam perencanaan kegiatan

\begin{tabular}{llcc}
\hline $\begin{array}{c}\text { Interval } \\
\text { (skor) }\end{array}$ & Klasifikasi & $\begin{array}{c}\text { Jumlah } \\
\text { (orang) }\end{array}$ & $\begin{array}{r}\text { Persentase } \\
(\%)\end{array}$ \\
\hline $5,670-8,175$ & Rendah & 9 & 25 \\
$8,176-10,681$ & Sedang & 12 & 33,33 \\
$10,682-13,185$ & Tinggi & 15 & 41,67 \\
\hline Jumlah & & 36 & 100,00 \\
Rata-rata $:$ & 9,81 (Sedang) & & \\
\hline
\end{tabular}

Sumber : Data Primer, 2017

\section{Partisipasi petani dalam pelaksanaan}

Partisipasi dalam tahap pelaksanaan kegiatan penangkaran benih kedeai yaitu meliputi segala kegiatan pelatihan, magang, dan kursus yang dilakukan penyuluh setempat. Hadir dalam pembagian benih kedelai, serta pemberian alat alat saprodi. Melakukan kegiatan budidaya sampai proses perawatan tanam benih kedelai sampai menghasilkan benih berkualitas. Partisipasi dalam pelaksanaan kegiatan, yaitu keterlibatan petani dalam aktivitas-aktivitas yang merupakan salah satu perwujudan program dalam bentuk tenaga kerja yang sepadan dengan hasil yang akan diterima.

Berdasarkan hasil data penelitian, bahwa sebagian besar responden yaitu sebanyak 18 orang $(50 \%)$ menyatakan partisipasi petani dalam pelaksanaan kegiatan penangkaran benih kedelai di Kecamatan Raman Utara masuk dalam klasifikasi sedang, 15 orang $(41,67 \%)$ diklasifikasikan tinggi, dan tiga orang $(8,33 \%)$ diklasifikasikan rendah. Petani di Desa Rejo Binangun sudah mau berpartisipasi aktif dalam pelaksanaan kegiatan penangkaran benih kedelai yang dapat dilihat dari rata-rata tingkat partisipasi petani dalam pelaksanaan kegiatan penangkaran benih kedelai yaitu sebesar 7,66 yang berada pada klasifikasi sedang.

Partisipasi dalam tahap pelaksanaan kegiatan penangkaran benih kedelai yaitu adanya kegiatan pelatihan magang, dan kegiatan kursus yang diadakan oleh para penyuluh. Kegiatan pelatihan yang di adakan yaitu kegiatan penyeleksian benih, uji lapangan untuk calon benih tanaman kedelai, dan kemampuan memupuk modal, kegiatan tersebut nantinya akan ada pembagian benih kedelai setiap kelompok tani, pemberian alat-alat saprodi dan melakukan kegiatan budidaya sampai proses perawatan tanaman hingga menghasilkan tanaman kedelai. Hasil penelitian partisipasi dalam tahap pelaksanaan dapat dilihat Tabel 6 .

Tabel 6. Sebaran responden berdasarkan tingkat partisipasi petani penangkar kedelai dalam pelaksanaan kegiatan

\begin{tabular}{cccc}
\hline $\begin{array}{c}\text { Interval } \\
\text { (skor) }\end{array}$ & Klasifikasi & $\begin{array}{c}\text { Jumlah } \\
\text { (orang) }\end{array}$ & $\begin{array}{c}\text { Persentase } \\
(\%)\end{array}$ \\
\hline $3,000-5,513$ & Rendah & 3 & 8,33 \\
$5,514-8,027$ & Sedang & 18 & 50 \\
$8,028-10,538$ & Tinggi & 15 & 41,67 \\
\hline Jumlah & & 36 & 100,00 \\
Rata-rata : 7,66 (Sedang) & & \\
\hline Sumber : Data Primer, 2017 & &
\end{tabular}




\section{Partisipasi petani dalam penilaian atau evaluasi}

Partisipasi dalam penilaian atau evaluasi program, yaitu keterlibatan petani dalam bentuk pengawasan pelaksanaan kegiatan penangkaran benih kedelai, pembuatan laporan pertanggung jawaban, serta evaluasi terhadap hasil yang telah dilaksanakan, dengan mengetahui apakah petani melihat secara langsung pelaksanaan kegiatan dan menyesuaikan pelaksanaan kegiatan apakah sudah sesuai dengan rencana awal kegiatan penangkaran benih kedelai. Kegiatan yang dilakukan dalam menilai atau mengevaluasi kegiatan penangkaran benih kedelai yaitu meliputi kegiatan memperoleh benih unggul dan berkualitas yang sesuai dengan rekomendasi dari dinas pertanian dan penyuluh, bantuan pupuk dan alat mesin pertanian yang diberikan oleh pemerintah, sehingga responden dapat menilai baik atau tidak untuk kelanjutan kegiatan penangkaran benih kedelai ke masa yang akan datang. Partisipasi petani dalam penilaian atau evaluasi kegiatan penangkaran benih kedelai sudah berjalan dengan baik.

Berdasarkan hasil penelitian, diketahui bahwa sebagian besar responden sebanyak 15 orang $(41,67 \%)$ menyatakan tingkat partisipasi petani dalam penilaian atau evaluasi program kegiatan penangkaran benih kedelai masuk dalam klasifikasi rendah, 10 orang $(27,78 \%)$ masuk dalam klasifikasi sedang, dan sisanya 11 orang $(30,56 \%)$ masuk dalam klasifikasi tinggi.

Berdasarkan Tabel 7 apabila dilihat dari angka rata-rata tingkat partisipasi petani dalam penilaian atau evaluasi kegiatan penangkaran benih kedelai berada pada klasifikasi sedang yaitu sebesar 5,17. Hal ini menunjukan masyarakat sudah mau untuk ikut serta dalam proses evaluasi terhadap program sudah dijalankan, hal ini guna untuk perbaikan kegiatan yang akan dijalankan pada waktu selanjutnya. Hal ini dapat dilihat pada Tabel 7.

Tabel 7. Sebaran responden berdasarkan tingkat partisipasi petani dalam penilaian dan evaluasi kegiatan penangkaran benih kedelai

\begin{tabular}{cccc}
\hline $\begin{array}{c}\text { Interval } \\
(\text { skor })\end{array}$ & Klasifikasi & $\begin{array}{c}\text { Jumlah } \\
\text { (orang) }\end{array}$ & $\begin{array}{c}\text { Persentase } \\
(\%)\end{array}$ \\
\hline $3,000-4,599$ & Rendah & 15 & 41,67 \\
$4,599-6,198$ & Sedang & 10 & 27,78 \\
$6,199-7,797$ & Tinggi & 11 & 30,56 \\
\hline Jumlah & 36 & 100,00 \\
\hline Rata-rata : 5,17 (Sedang) & & \\
\hline Sumber : Data Primer, penelitian 2017 &
\end{tabular}

4. Partisipasi petani pada tahap menikmati hasil program dan manfaatnnya

Partisipasi petani dalam menikmati hasil program dan pemanfaatannya merupakan keikutsertaan petani dalam memaksimalkan manfaat yang mungkin diperoleh. Berdasarkan hasil penelitian, tingkat partisipasi anggota kelompok tani dalam pengambilan manfaat kegiatan penangkaran benih kedelai berada dalam klasifikasi tinggi. Artinya, petani sudah ikut dan merasakan manfaat secara langsung dari kegiatan penangkaran benih kedelai yang telah dilakukan, dengan tujuan untuk menjadikan benih kedelai yang berkualitas baik. Kegiatan penangkaran benih kedelai memiliki tujuan dan maksud yaitu supaya petani sadar bahwa hasil yang diterima selama menikmati dari kegiatan pelatihan ini cukup banyak seperti mendapatkan wawasan dan pengetahuan dalam menghasilkan benih-benih kedelai yang berkulitas yang nantinya dapat berdampak dalam segi sosial maupun segi ekonomi.

Menurut Batubara, Effendi, Prayitno (2016), tingkat partisipasi pada tahap menikmati hasil program dan manfaatnya dapat diketahui dari ada tidaknya keuntungan secara ekonomi, fisik yang didapat setelah semua tahapan dalam pelaksanaan program terlaksana, manfaat lain yang dirasakan oleh petani berupa manfaat bantuan pemerintah yaitu alat dan mesin pertanian dan pemberian benih unggul untuk menunjang kegiatan usahatani petani, kegiatan penyuluhan, serta pendampingan kerjasama dari berbagai pihak.

Berdasarkan hasil penelitian yang sudah dilakukan diketahui bahwa dari 16 orang dapat dilihat masuk dalam klasifikasi rendah $(44,44 \%)$ lima orang petani masuk dalam klasifikasi kelas sedang pada tahap menikmati hasil dan pemanfaatannya $(13,89 \%)$ serta 15 orang petani masuk dalam klasifikasi tinggi $(41,67 \%)$ dapat dilihat pada Tabel 8.

Tabel 8. Sebaran responden berdasarkan partisipasi petani pada tahap menikmati hasil dan manfaatannya

\begin{tabular}{lccc}
\hline Interval (skor) & Klasifikasi & $\begin{array}{c}\text { Jumlah } \\
\text { (Orang) }\end{array}$ & $\begin{array}{c}\text { Persentase } \\
(\%)\end{array}$ \\
\hline $3.000-5,041$ & Rendah & 16 & 44,44 \\
$5,042-7,083$ & Sedang & 5 & 13,89 \\
$7,084-9,125$ & Tinggi & 15 & 41,67 \\
\hline Jumlah & 36 & 100 \\
\hline Rata-rata & 6,14 (Sedang) & \\
\hline Sumber : Data Primer, 2017
\end{tabular}




\section{Pengujian Hipotesis}

Variabel $\mathrm{X}$ adalah faktor-faktor yang berhubungan dengan tingkat partisipasi anggota kelompok tani dalam kegiatan penangkaran benih kedelai yang meliputi jenis pendidikan nonformal, tingkat motivasi petani, tingkat kekosmopolitan petani dan tingkat pengetahuan petani dalam kegiatan penangkaran benih kedelai. Variabel $\mathrm{Y}$ adalah partisipasi anggota kelompok tani dalam kegiatan penangkaran benih kedelai meliputi partisipasi dalam perencanaan, partisipasi dalam pelaksanaan kegiatan penangkaran benih kedelai, partisipasi dalam tahap penilaian atau evaluasi kegiatan penangkaran benih kedelai dan partisipasi dalam pengambilan manfaat.

Hubungan antara variabel $\mathrm{X}$ dan variabel $\mathrm{Y}$ dianalisis dengan menggunakan uji korelasi Rank Spearman dengan menggunakan program SPSS 20. Hasil pengujian statistik terhadap faktor yang berhubungan dengan tingkat partisipasi anggota kelompok tani dalam kegiatan penangkaran benih kedelai.

Berdasarkan hasil penelitian, maka dapat diketahui rekapitulasi data hasil pengujian statistik Rank Spearman yang menunjukkan bahwa hasil perhitungan yang didapat yaitu untuk $\left(\mathrm{X}_{1}\right)$ jenis pendidikan nonformal, $\left(\mathrm{X}_{3}\right)$ tingkat kosmopolit, $\left(\mathrm{X}_{4}\right)$ tingkat pengetahuan petani dapatdi simpulkan keputusan yaitu hipotesis diterima, sedangkan variabel tingkat motivasi $\left(\mathrm{X}_{2}\right)$, tidak memiliki hubungan yang tidak nyata dengan tingkat partisipasi anggota kelompok tani dalam kegiatan penangkaran benih kedelai. Berikut ini adalah pengujian hipotesis dan pembahasan faktor-faktor yang berhubungan dengan partisipasi anggota kelompok tani dalam kegiatan penangkaran benih kedelai, sedangkan untuk $\left(\mathrm{X}_{2}\right)$ tingkat motivasi yaitu hipotesis ditolak, hasil data tersebut dapat dilihat pada Tabel 9.

Tabel 9. Hasil analisis korelasi Rank Spearman antara variabel $\mathrm{X}$ dan $\mathrm{Y}$

\begin{tabular}{ccccc}
\hline $\begin{array}{c}\text { Variabel } \\
\mathrm{X}\end{array}$ & $\begin{array}{c}\text { Koefisien } \\
\text { Korelasi } \\
(\mathrm{rs})\end{array}$ & $\begin{array}{c}\text { Sig. } \\
(1- \\
\text { tailed })\end{array}$ & $\mathrm{A}$ & Keputusan \\
\hline $\mathrm{X}_{1}$ &, $355^{*}$ &, 017 & 0,05 & $\begin{array}{l}\text { Hipotesis } \\
\text { diterima }\end{array}$ \\
$\mathrm{X}_{2}$ &, 206 &, 114 & 0,05 & $\begin{array}{l}\text { Hipotesis } \\
\text { ditolak }\end{array}$ \\
$\mathrm{X}_{3}$ &, $440^{* *}$ &, 004 & 0,05 & $\begin{array}{l}\text { Hipotesis } \\
\text { diterima }\end{array}$ \\
$\mathrm{X}_{4}$ &, $585^{* *}$ &, 000 & 0,05 & $\begin{array}{c}\text { Hipotesis } \\
\text { diterima }\end{array}$ \\
\hline
\end{tabular}

Sumber : Data Primer, penelitian 2017
Jenis pendidikan nonformal mempengaruhi keikutsertaan responden dalam mengikuti kegiatan penangkaran benih kedelai. Responden yang mengikuti jenis pendidikan formal yang lebih tinggi cenderung untuk mengikuti kegiatan penangkaran benih kedelai. Hal ini dikarenakan pemikiran responden tersebut sudah lebih maju untuk meningkatkan produksi serta produktivitas usahatani kedelai yang akan meningkatkan pendapatan dan kesejahteraan responden dan keluarganya.

Hasil uji korelasi Rank Spearman mengenai hipotesis tentang jenis pendidikan nonformal $\left(\mathrm{X}_{1}\right)$ dengan tingkat partisipasi anggota kelompok tani dalam kegiatan penangkaran benih kedelai menunjukkan nilai signifikansi sebesar 0,017 . Nilai signifikansi sebesar 0,017 lebih kecil dibandingkan dengan nilai $\alpha$ sebesar 0,05 pada taraf kepercayaan 95 persen, maka dapat diambil kesimpulan terdapat hubungan yang nyata antara jenis pendidikan nonformal dengan tingkat partisipasi anggota kelompok tani dalam kegiatan penangkaran benih kedelai.

Hasil uji korelasi Rank Spearman mengenai hipotesis tentang tingkat motivasi petani $\left(\mathrm{X}_{2}\right)$ dengan tingkat partisipasi anggota kelompok tani dalam kegiatan penangkaran benih kedelai menunjukkan nilai signifikansi sebesar 0,114.

Nilai signifikansi sebesar 0,114 lebih besar dibandingkan dengan nilai $\alpha$ sebesar 0,05 pada taraf kepercayaan 95 persen, maka dapat diambil kesimpulan yaitu tidak terdapat hubungan yang nyata antara tingkat motivasi petani dengan tingkat partisipasi anggota kelompok tani dalam kegiatan penangkaran benih kedela. Hal ini dikarenakan tingkat motivasi petani di Desa Rejo Binangun kecamatan Raman Utara tidak bervariasi. Hal ini dikarenakan hasil data dengan kuesioner petani cenderung memberikan jawaban yang sebagian sama oleh karena itu hasil yang didapat dan diolah tidak menunjukkan data yang bervariasi.

Hasil penelitian ini sesuai dengan penelitian Mulyanto (2007) menyatakan bahwa variabel tingkat motivasi dan tidak berpengaruh signifikan terhadap kinerja pegawai dan faktor lainnya. Hasil penelitian berbeda ditemukan Pramudyo (2010) yang menyatakan bahwa terdapat pengaruh positif dan signifikan antara motivasi, kompetensi dan kepemimpinan terhadap kinerja dosen, sedangkan lingkungan kerja tidak berpengaruh signifikan. 
Hasil uji korelasi Rank Spearman mengenai hipotesis tentang tingkat kekosmopolitan petani $\left(\mathrm{X}_{3}\right)$ dengan tingkat partisipasi anggota kelompok tani dalam kegiatan penangkaran benih kedelai menunjukkan nilai signifikansi sebesar 0,004 lebih kecil dibandingkan dengan nilai $\alpha$ sebesar 0,05 pada taraf kepercayaan 95 persen. Hal ini dapat diambil kesimpulan yaitu terdapat hubungan yang nyata antara tingkat kekosmopolitan dengan tingkat partisipasi anggota kelompok tani dalam kegiatan penangkaran benih kedelai.

Hasil penelitian ini sejalan dengan hasil penelitian Triana (2017) bahwa tingkat kekosmopolitan petani berhubungan nyata dengan partisipasi petani dalam suatu kegiatan, hal ini dikarenakan sebagian responden jarang mengadakan pertemuan anjangsana dengan tokoh masyarakat lain, dan sebagian responden lainnya tidak memanfaatkan media masa seperti televisi dan surat kabar untuk memperoleh informasi tentang usaha peningkatan produksi usahataninya.

Responden lebih memanfaatkan media elektronik sebagai sarana hiburan seperti menonton televisi dan mendengarkan musik, atau membaca berita di surat kabar tentang informasi di luar kegiatan pertanian. Namun Penelitian ini tidak sejalan dengan hasil penelitian yang dilakukan Wijaya (2010) yang menyatakan bahwa tidak terdapat hubungan yang nyata antara tingkat kekosmopolitan dengan tingkat partisipasi petani.

Hasil pengujian hipotesis menunjukkan bahwa ada hubungan nyata antara tingkat kekosmopolitan dengan partisipasi anggota kelompok tani dalam kegiatan penangkaran benih kedelai. Hasil data tersebut didapat dari uji korelasi Rank Spearman yang diperoleh hasil nilai signifikansi sebesar $0,004 \leq \alpha=0,05$.

Hasil uji korelasi Rank Spearman mengenai hipotesis tentang tingkat pengetahuan petani tentang program $\left(\mathrm{X}_{4}\right)$ dengan tingkat partisipasi anggota kelompok tani menunjukkan nilai signifikansi sebesar 0,0001. Nilai signifikansi sebesar 0,0001 lebih kecil dibandingkan dengan nilai $\alpha$ sebesar 0,05 pada taraf kepercayaan 95 persen, maka dapat diambil kesimpulan terdapat hubungan yang nyata antara tingkat pengetahuan petani tentang program dengan tingkat partisipasi anggota kelompok tani dalam kegiatan penangkaran benih kedelai.

\section{KESIMPULAN}

Berdasarkan hasil penelitian maka dapat disimpulkan bahwa tingkat partisipasi anggota kelompok tani dalam kegiatan penangkaran benih kedelai di Kecamatan Raman Utara Kabupaten Lampung Timur termasuk ke dalam klasifikasi sedang. Selain itu faktor - faktor yang berhubungan nyata dengan tingkat partisipasi petani dalam penangkaran benih kedelai adalah jenis pendidikan nonformal, tingkat kekosmopolitan petani dan tingkat pengetahuan petani, sedangkan tingkat motivasi tidak berhubungan nyata.

\section{DAFTAR PUSTAKA}

Andreeyan. 2014. Strategi-Strategi Pembangunan Masyarakat. Pustaka Pelajar. Yogyakarta.

Batubara RH, Effendi I, dan Prayitno RT. 2016. Partisipasi masyarakat dalam Program Gerakan Serentak Membangun Kampung (GSMK) di Kecamatan Gedung Aji Baru Kabupaten Tulang Bawang. JIIA: 4(1): 111117.http://jurnal.fp.unila.ac.id/index/JIA/arcle /view/1221/1118. [5 juni 2018].

Badan Pusat Statistik. 2015. Lampung Timur Dalam Angka 2012. BPS Lampung Timur. Sukadana.

Balai Konservasi Sumber daya alam (BKSDA). 2014. Penangkaran tumbuhan dan satwa liar Balai Konservasi Sumber daya alam Bali. https://www.ksdabali.go.id/perijinan/tumbuha ndansatwaliar/penangkaran/tumbuhandansatw aliar/. [5 juni 2018]

Davis K. 2000. Perilaku Dalam Organisasi, Edisi Ke tujuh. Erlangga. Jakarta.

Hadi AR, Effendi I, dan Hasanudin T. 2013. Peranan kader pemberdayaan masyarakat desa dan partisipasi masyarakat pada program Program Nasional Pemberdayaan Masyarakat Mandiri pedesaan (PNPM-MP) di Kecamatan Wonosobo Kabupaten Tanggamus. JIIA: 1(1):6672. http://jurnal.fp.unila.ac.id/index.ph p/JIA/article/view/133/137. [5 Juni 2018].

Mulyanto HR 2007. Sungai dan Sifat-Sifatnya. Graha Ilmu. Yogyakarta.

Nasir M. 1998. Metode Penelitian, Ghalia Indonesia. Jakarta.

Pramudyo A. 2010. Analisis faktor-faktor yang mempengaruhi kinerja dosen negeri pada kopertis wilayah V Yogyakarta. JBTI, 1 (1) 111. http://journal.umy.ac.id/index.php/bti/arti cle/view/2407 [3 Maret 2017].

Rakhmat J. 2002. Metodelogi Penelitian Komunikasi. PT Rosda Karya. Bandung. 
Siegel, S. 1986. Statistik Non-Parametrik Ilmuilmu Sosial. PT Gramedia Pustaka Utama. Jakarta.

Singarimbun M dan S Effendi. 1989. Metode Penelitian Survai. LP3ES. Jakarta.

Triana SR, Rangga KK, dan Viantimala B.2017. Partisipasi petani dalam program upaya khusus peningkatan produksi padi, jagung dan kedelai (UP2PJK) di Kecamatan Seputih
Raman Kabupaten Lampung Tengah. JIIA: 5(4)1755-4618. http://jurnal.fp.unila.ac.id/in dex.php/JIA. [5 Juni 2018].

Wijaya Y. 2010. Partisipasi Petani Dalam Program Kemitraan (Kemitraan Antara Petani Jagung dan PT Java Mitra Sejahtera) di Desa Sindang Sari Kecamatan Tanjung Bintang Kabupaten Lampung Selatan. Skripsi. Universitas Lampung. Lampung. 